\section{Teju Adisa-Farrar}

I am a geographer, writer, poet, and facilitator. I am focused on environmental and cultural equity. Connecting the dots between issues by centering space, place and identity. Rooted in a politics of de- : decolonization, decentralization and decommodifcation. I look to historic Black geographies and urban ecologies, including: nature, activism, and art--to imagine alternative futures. I use speculative geography as a type of Sci-Fi to envision Black life after social death and in the wake of climate change. By submitting this piece, I hope to affirm this experimental

process and extend my belief in the possibilities.

\section{All Mermaids are Black}

When the giant wave comes washing over our bodies

Black people will become mermaids, and indigenoous people will become seeds.

What will you become?

\section{Critical Fabulation:}

The outcome of this method is a "recombinant narrative,"which "loops the strands" of incommensurate accounts and which weaves present, past, and future... ${ }^{1}$

Two years ago, I heard a young scholar named Kali Tambreé ask: "when they jumped from the slave ships, where do they go?" This is a response.

Some matter that ends up in the ocean settles to the sea floor as a form of sediment. Over time, this sediment becomes rock and may eventually - through pressure and temperature change be pushed up above the surface again. When they jumped from the slave ships, they became the sea floor...or rather, returned to the seafloor to become the earth itself. In millions of years, we will know that continents are made up of fugitive Africans who jumped into the ocean to remap their freedom.

1 Hartman, Saidiya "Venus in Two Acts." Small txe 12, no. 2 2008: 1-14. muse.jhu.edu/article/241115

$$
\text { Page } 32
$$

Root Work Journal

Vol- 1 Issue- 2
In August of 1619, 20 Africans arrived at Point Comfort after being stolen by British Pirates from a Portugese Slave Ship, which originally stole them from Angola. ${ }^{2}$ Earlier than 1500, Portuguese colonists were in the business of stealing bodies from the continent of Africa ${ }^{3}$ and sailing them across water. On the coasts of the Americas lie Black communities, scattered there by slave ships. Just as soon as we were "imported," we were fugitive.

When God made mountains

He made runaway slaves

The middle passage is not all we are made of. Like a lunar eclipse it overshadows - but does not destroy our light. Our memory of freedom was longer than our experience of bondage. Like the tides being pulled by the moon's gravitational force, in the light of the moon we were propelled to cultivate freedom after arriving on the shores of the Americas. In the thick of the forests we became maroons, always returning to the water to say thank you. At the edge of rivers, above the waterfalls we became cimarrones, navigating waterwaysto liberation. Giving libation to Yemaya and going back for others. We are coastal people, shorelines are the site of our refusal. On both sides of the ocean, we refused. In the middle of the ocean, we refused. On the bottom of the ocean, we refuse. In the wake $e^{5}$, we refuse.

We are Black because of our relationship to water, because of our traversal and dispersal across waters, because of our spiritual connection to water. Our communities developed along coastline, sometimes as maroons - other times as survivors. The pathways of sustenance created by indigensous peoples alongside nature, allowed for fugitive Africans to adapt their knowledge from home to the terrain of the Americas asthey built self-sustaining maroon communities. Braiding seeds from home into their hair. Braiding maps to free Black villages into their hair. Always returning to the ports, to the water, to extricate others.

2 Hannah-Jones, Nikole. “The 1619 Project." The New York Times, The New York Times, 14 Aug. 2019, www.nytimes.com interactive/2019/08/14/magazine/1619-america-slavery.html.

3 "Brazil: Five Centuries of Change." Brazil Five Centuries of Change, Brown University Library: Center for Digital Scholarship, library.brown.edu/create/fivecenturiesofchange/chapters/chapter-2/african-slavery/. 4 Giovanni, Nikki. Chasing Utopia. William Morrow, 2013.

5 Sharpe, Christina Elizabeth. In the Wake:on Blackness and Being. Duke University Press, 2016. Page 33 
If the only accounts of freedom and agency during slavery are oralstories, then we must believe these stories are the truth. If the only maps deemed valid show our bondage, then we must look to the ocean for evidence of our collective manumission. We must "uncover the sea's dynamism as a maroon geography that alters with time and space. ${ }^{16}$ After all, we will all go back to the ocean anyway. Some of us are already there.

We are situated on the edge of land, closest to water. Still in the wake of dispossession. Still most vulnerable to the ocean. Still closest to the levees. Still allowed to be flooded or washed out. Still expected to drown asthe sea level rises. Still. Eventually the water becomes still. We were not supposed to survive, but the flesh of our ancestors live in the currents. Reaching every side of the Triangular Trade; Western comfort is made from us. Point Comfort was not our beginning and Igbo Landing was not our ending. We are transitioning. The ashes of our ancestors are building worldsfor us on the seafloor.

We say we can't breathe. Our lungs are collapsing, becoming gills. We were not meant to breathe in this world. Our skin is thick, not able to propel bullets, but so that we are hydrodynamic. Our ritual movements: fluid, flowing against the pressure of society - we are preparing ourselves to move through the resistance of water. We are evolving because the ocean will reclaim the land.

We will all be submerged.

Black people will emerge under water: our eyes open, able to breathe, think, and live. We will not be destroyed.

6 Dunnavant. Justin P. “Have Confidence in the Sea: Maritime Maroons and Fugitive Geographies.” Antipode, 2020 doi:10.1111/anti.12695.

Page 34

Root Work Journal

Vol- 1 Issue- 2

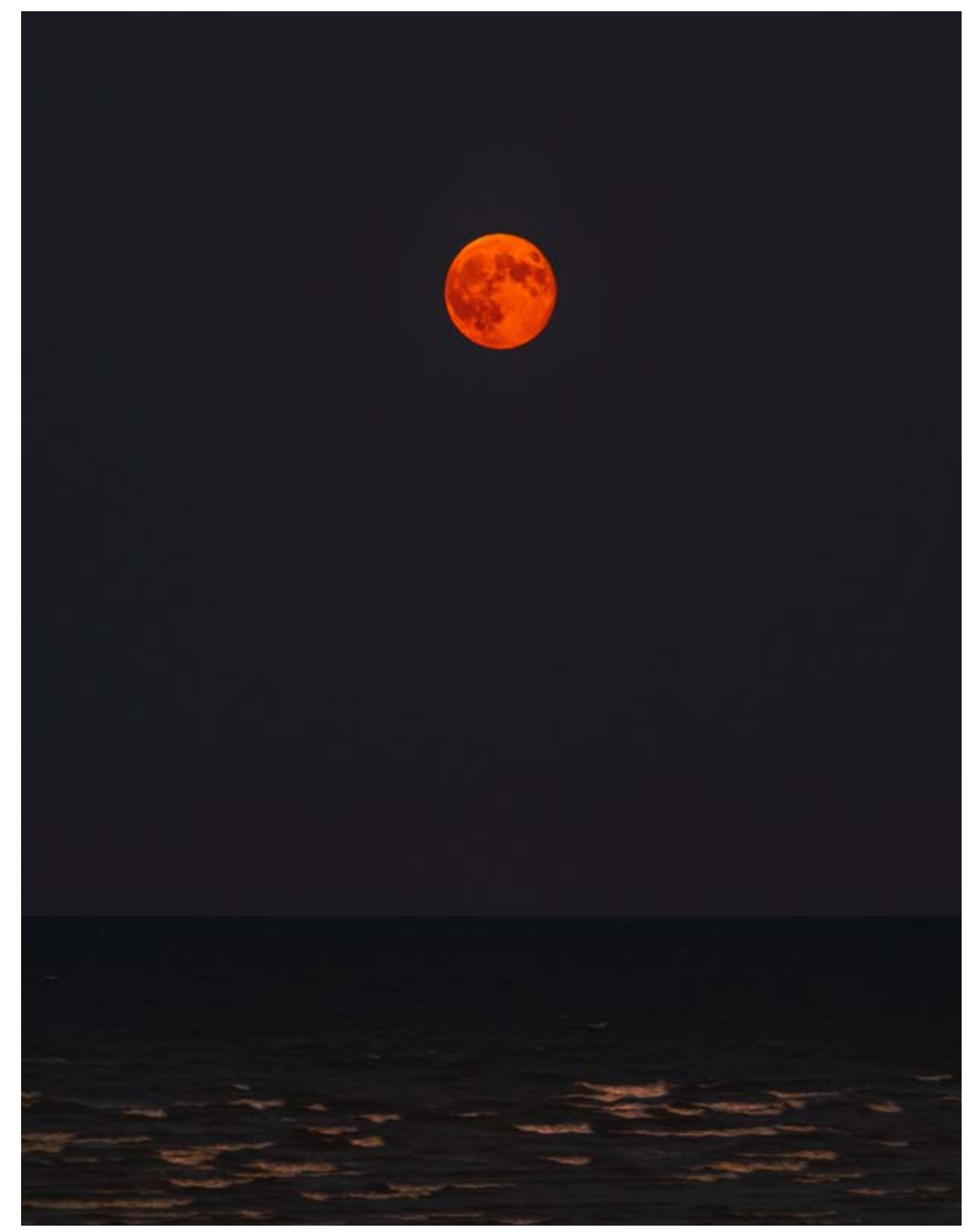

